
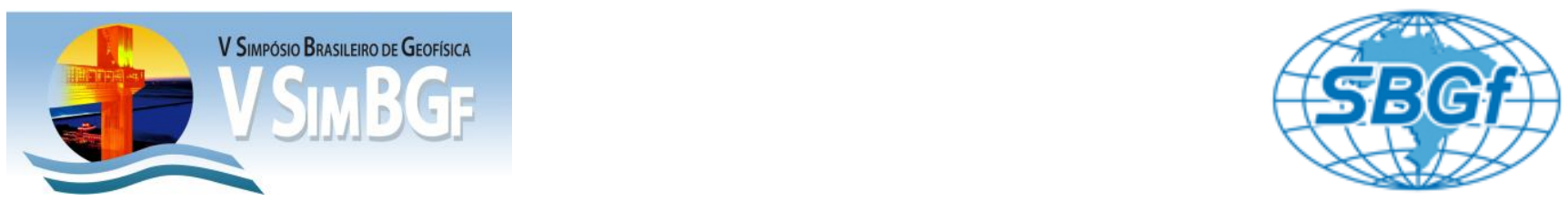

\title{
USING 3D SEISMIC FOR COAL BEDS MAPPING IN COLOMBIA
}

\author{
Juan Carlos Ruiz ${ }^{1}$, Marcos do Amaral $^{2}$ \\ ${ }^{1}$ OGX Petróleo e Gas Ltda. Colombia and ${ }^{2} O G X$ Petróleo e Gas Brasil.
}

Copyright 2012, SBGf - Sociedade Brasileira de Geofísica

Este texto foi preparado para a apresentação no V Simpósio Brasileiro de Geofísica, Salvador, 27 a 29 de novembro de 2012. Seu conteúdo foi revisado pelo Comite Técnico do V SimBGf, mas não necessariamente representa a opinião da SBGf ou de seus associados. E proibida a reprodução total ou parcial deste material para propósitos comerciais sem prévia autorização da SBGt.

\section{Resume}

In the northern department of Guajira - Colombia famous giant coal deposits were discovered since 1982 and open pit exploitation has been producing for more than 30 years. In the southern Guajira, Mining coal and oil exploration wells have proved that the coal deposits are continuous to the south but under a thick tertiary alluvial sequence that makes difficult the traditional exploitation. How to image and map the coal beds to plan an underground mining? The answer was a high quality 112 $\mathrm{km}^{2}$ of 3D seismic focused on the low deep reflectors and tied up with 40 control wells in order to correlate coal beds and with a detailed processing work and seismic inversion obtaining the best possible seismic resolution.

\section{Introduction}

The development of the seismic acquisition and processing was used in Colombia for modeling one of the most giant coal deposit in the world. The Ranchería basin in the northern Colombia was producing coal of high quality for the last 30 years in the Cerrejón open pit mine rising a production of $32 \mathrm{M}$ Ton during the last year (www.cerrejon.com, 2011). At $30 \mathrm{kms}$ South-West from the Cerrejón Mine, the mining company CCX, member of the Brazilian group EBX, found the continuity of the coal Cerrejón Formation with 40 exploration wells campaign confirming one enormous coal deposit at an average of $500 \mathrm{~m}$ underground. A geological model made just with exploration wells lets a large uncertainty of the structural framework of the deposit but allows us to know the deep and quality of the coal beds. The best way to improve the model in order to project a future development for an underground mining was a 3D seismic (Fig. 1) focused on the depth of 400 to $2000 \mathrm{~m}$ where the Late Paleocene Cerrejón Fm. was found (C.A. Jaramillo et al. 2007) Near 600 to $1200 \mathrm{~ms}$ in a TWT seismic section.

The possibility to obtain a $3 D$ volume in where the whole package of the coal could be visualized was the most important objective reached with this exploration program. The most recent acquisition equipment, including multicomponent receivers and the present capacity of the processing centers to manage big data amounts and specialized algorithms permitted a nice imaging for interpretation and mapping of different coal layers which is the basis for the mining design. The S-wave data was not yet utilized in this first mapping step but represents an important database that will provide stress information that will indicates the best direction of the tunnels construction for the future development of the mine.

The initial resolution of the seismic image obtained after the $\mathrm{P}$-wave pre-stack time migration was enough for the objective to visualize the whole package of tested coal beds in the exploration wells (more than 30 beds) and the structural framework that affected it. Even with a good frequency content $(20-50 \mathrm{~Hz})$ reached in the coal section it was not enough to differentiate each mineralized seam. The present state of the seismic inversion processing taking into account all the well information permits a new imaging in where at least 12 of the major recognized coal beds could be mapped.

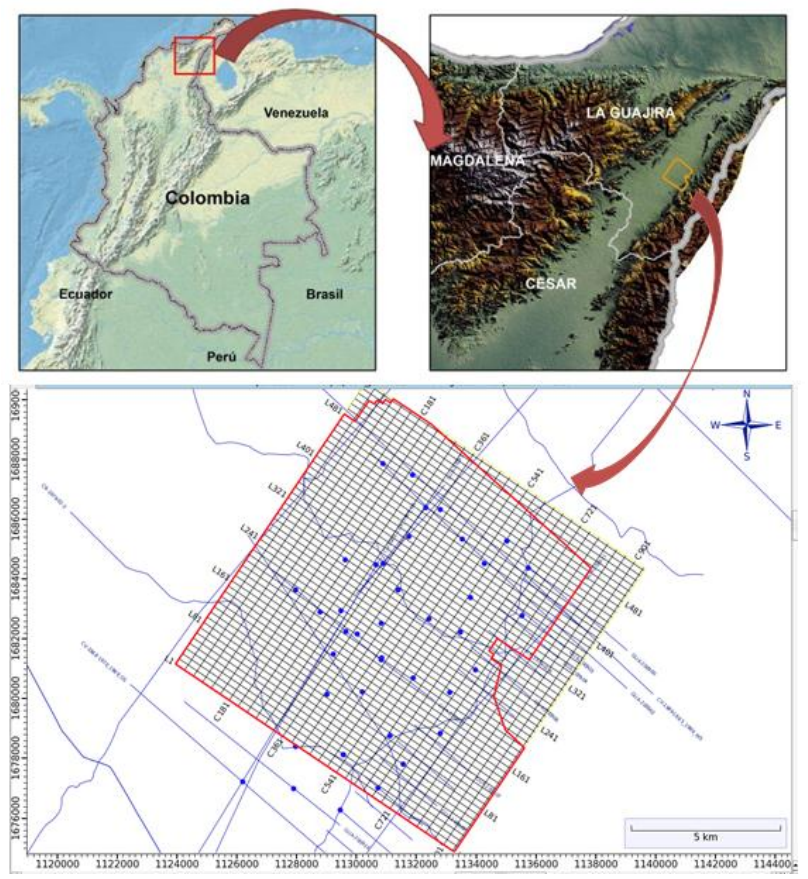

Figure 1 - Ranchería basin in northern Colombia and location of the coal exploration project: wells (blue dots) + $3 D$ seismic program (112 Km2).

\section{Methodology}

For the case of the San Juan del Molino 3D (SJDM 3D) a total area of $112 \mathrm{Km}^{2}$ was acquired with a very dense amount of shots per $\mathrm{Km}^{2}$ (113) and a high number of receivers recording (3240 per shot). The maximum offset was $2600 \mathrm{~m}$ focused on the coal deposit tested by the exploration wells around $1000 \mathrm{~m}$ depth (Fig. 2). 


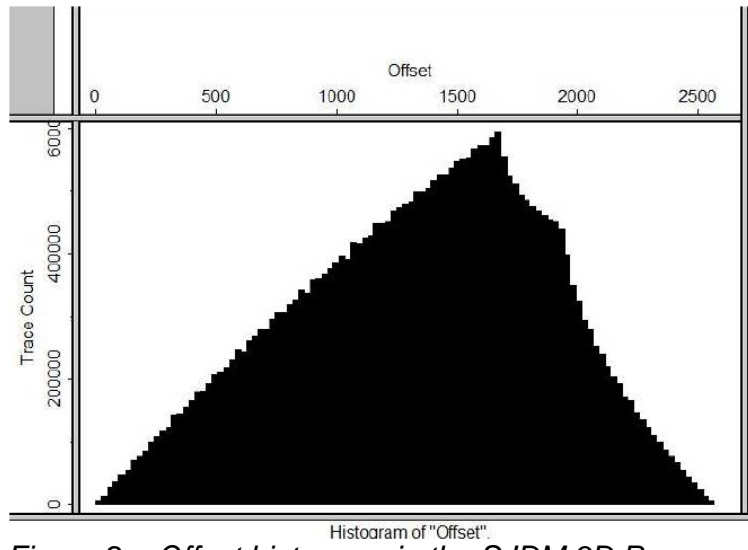

Figure 2 - Offset histogram in the SJDM 3D Program.

A Sercel $428 \mathrm{XI}$ acquisition system was used with DSU3 multi-components receivers in order to record additional S-wave data to be used in a future stress data control. A nominal fold of 90 was reached covering near the total of the studied area. In this case the final grid in subsoil is a bin of $12{ }^{*} 21 \mathrm{~m}$.

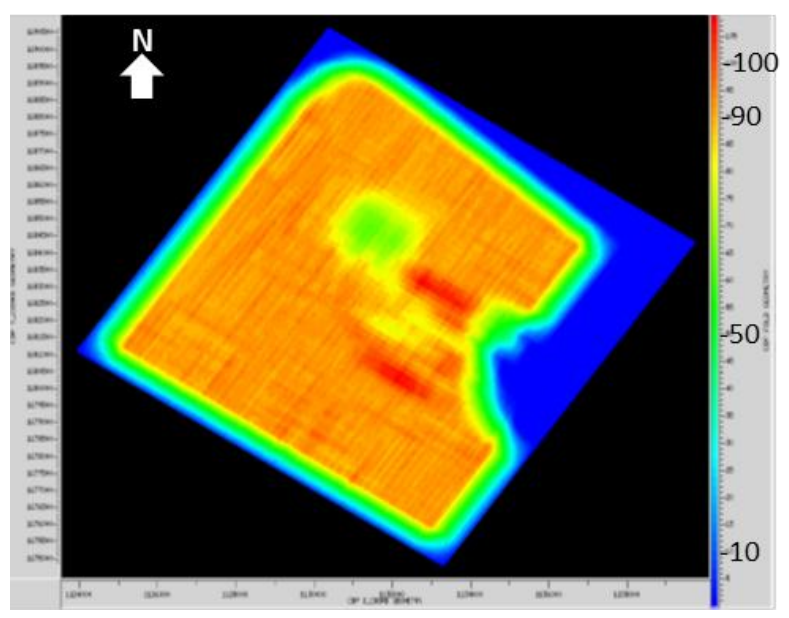

Figure 3 - High coverage (Fold) San Juan del Molino 3D except a $6 \mathrm{Km}^{2}$ area near the center volume where exist an environmental restriction (green area).

All the information obtained by the acquisition company was processed in Colombia and China. Field information was acquired with receivers type DSU (3-components of waves $X, Y \& Z$ ) generating a huge amount of data (> 3TB). In Colombia the $P$ wave ( $z$ ) was processed from the acquisition moment and $S$ wave $(X \& Y)$ data are handled in China. The exhaustive work process that was invested in the seismic program of San Juan del Molino aims to achieve the best possible resolution in the coal Cerrejon formation sequence to define a geological model, supported by the drilling of wells.

The first processing work of the San Juan del Molino 3D seismic program was conventional primary compressive wave ( $P$ wave). A good coverage of the interest area was obtained as shown Fig. 3. This image shows how the subsoil has high coverage (> 80 times colors from yellow to red) in almost all of the area registered.

Results showed that the efforts made in the acquisition generated an image of the subsoil which surpassed all former campaigns of 2D seismic existing in the area.

\section{Results}

An additional effort looking for better resolution seismic image with a hard work of noise attenuation, cleaning of defective traces and a detailed velocity control was realized. The final product of this process showed an improvement in the interest area of the coal deposit details and showed that, every extra effort brings better data. In figure 4 an example shows an intermediate Inline where the coal section is clearly imaged and correlated with wells in where a density log curve (in red) shows the coal deposit under a regional unconformity.

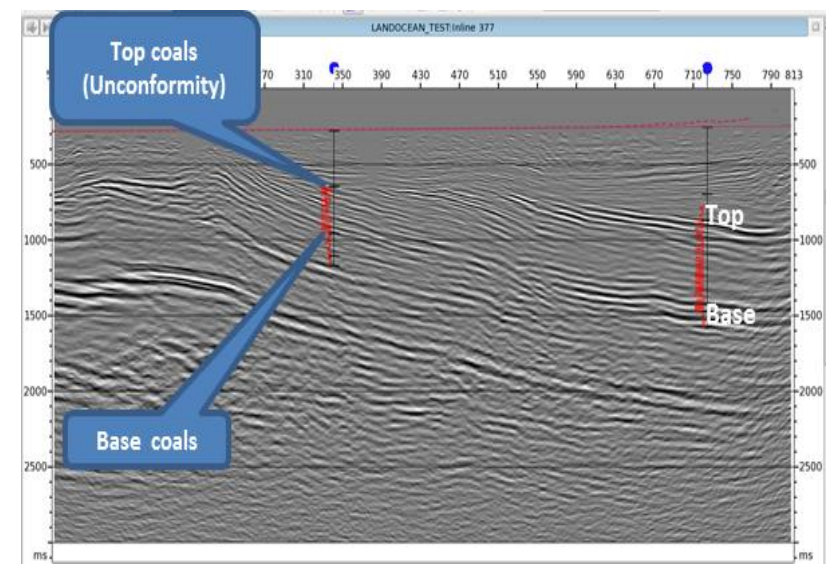

Figure 4 - Process result (Migration) Note coal section in well logs (red).

The 2 drilled wells shows the density log in red and the nice tie between the red picks of coal beds and the reflection from the cerrejón Formation. Its important to note that the resolution of the seismic, in this case, based on the main frequency that is $50 \mathrm{~Hz}$, by $\lambda=V / f$ equation, the minimum identification thickness $\lambda / 4$ is higher than $10 \mathrm{~m}$.

The San Juan del Molino project is located in the southern sector of La Guajira Department. Although the seismic program is on the Valley and presents no major differences in topography, the regional geology evidence compressive efforts. The Perijá Mountains limit to the east on the border with Venezuela and to the NW the Sierra de Santa Marta. The northern section of the Valley is clearly cut by the huge strike slip Oca fault (O.F. Fig. 5). This environment gives the idea that the acquired seismic volume finds a confluence of efforts, with little evidence on the surface. 


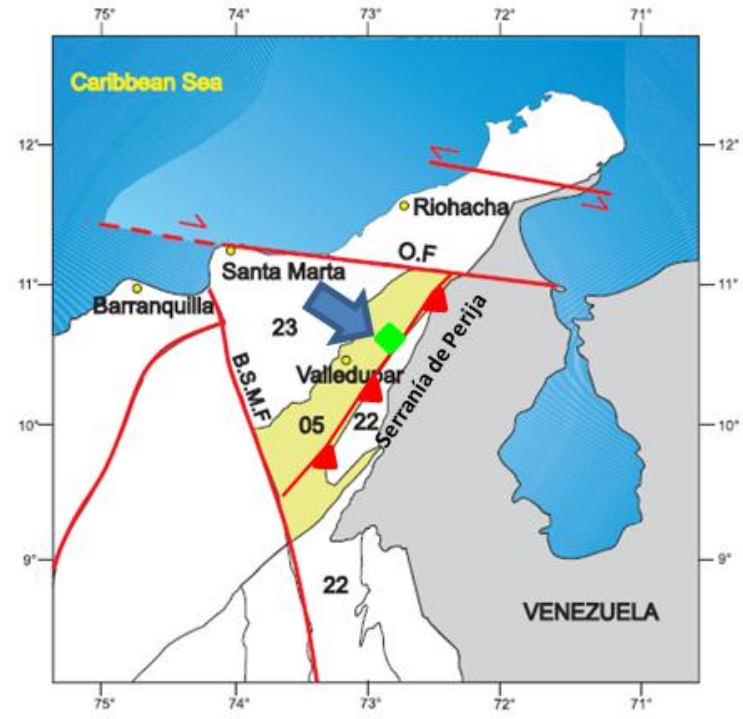

Figure 5 - Northern Colombia Structural schema (Modified from $A N H, 2007$ )

According to the regional information the interpretation done in the seismic volume includes a compressive structural behavior where a probable system of reverse low angle faults with NW vergence, parallels on the edge of the Serranía del Perijá (Bayona et al., 2011), is cut by SW-NE direction faults that generate a structure in positive flower (Fig. 6).

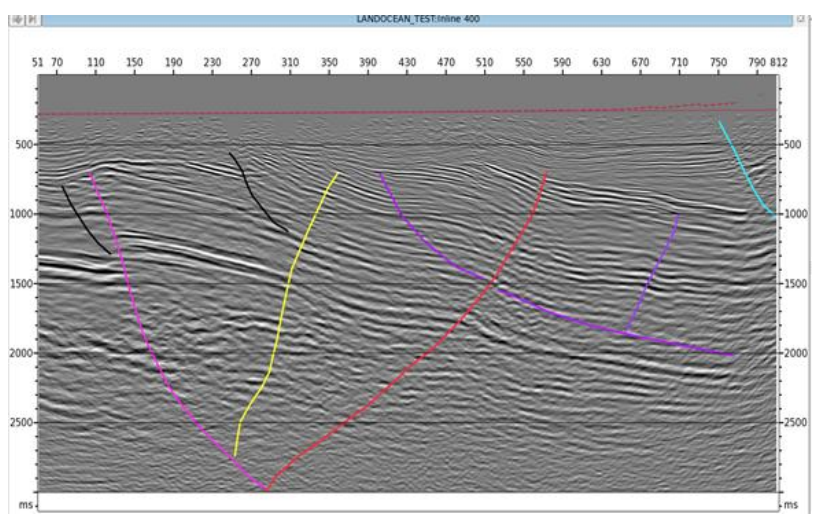

Figure 6 - Low angle fault cut by strike slip faults.

Following the surfaces for each of the interpreted faults defines the structural schema that was the basis of the interpretation (Fig. 7)

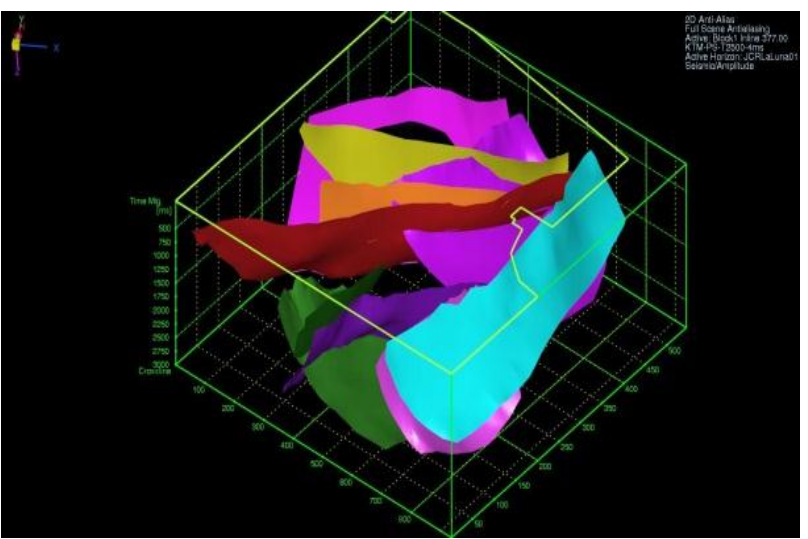

Figure 7 - Fault surfaces interpretation.

The fault control was very important in the time-slices sections of the cube in where the trend of those structures is clear and it is possible to follow the fault planes. Figure 8 shows a time-slice at $900 \mathrm{~ms}$ showing the fault interpretation.

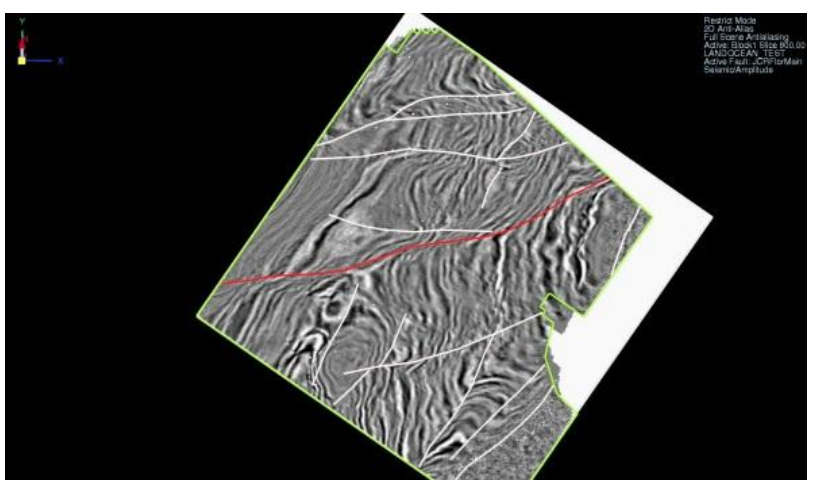

Figure 8 -Time slice of the volume showing faults interpretation.

Once the complex structural framework was defined, the Cerrejón Fm. objective of the geological model was interpreted between, in this case, the basis of alluvial sediment or Eocene unconformity (roof of the Cerrejón $\mathrm{Fm})$ and the base of coals. The maximum thickness drilled in the area was $900 \mathrm{~m}$ of the complete Cerrejon Formation that is comparable to the $1000 \mathrm{~m}$ measured in the northern Cerrejón Coal Mine (Bayona et al. 2004).

The Fig. 9 shows the interpretation where the basis of the alluvial is orange (top coals) and the base coal is dark blue. The orange horizon is the above mentioned regional unconformity that causes the total erotion of the Cerrejón formation to the NW area of the seismic volume. 


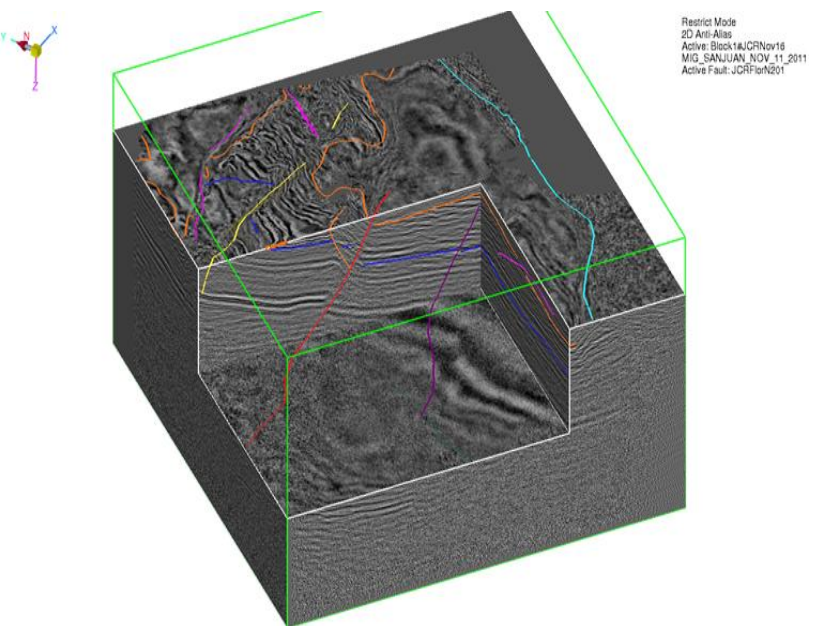

Figure 9 - 3D volume interpretation for coal deposit.

During the interpretation work, the data received from the new drilling was integrated into the project and confirmed the geological model.

Grids or generated surfaces are mapped taking into account the faults that cut such surfaces obtaining the final result of the interpretation. The Fig. 10 shows the map of Manto00 surface or base of coals.

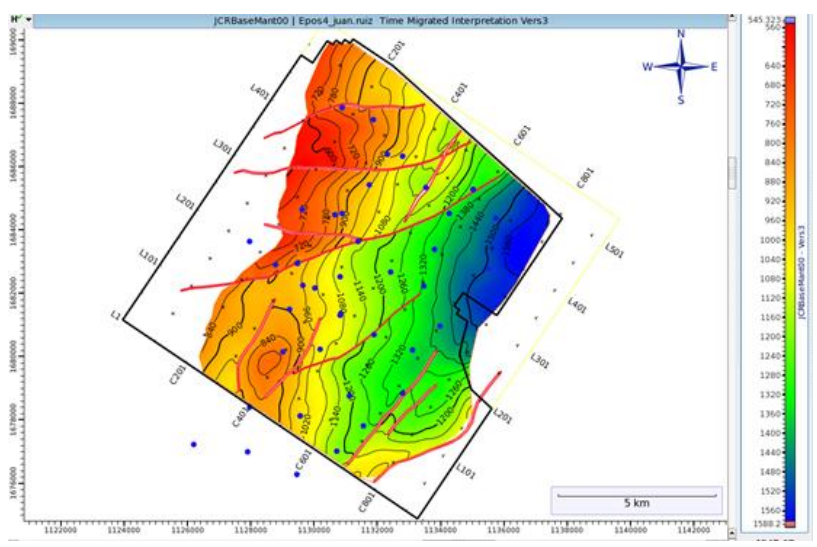

Figure 10 - Base of coals time map. Pinch out formation to NW.

A work of seismic inversion using a large amount of well data to evaluate the coal formation boreholes in the area of the 3D program will be also carried out. This seismic inversion will use the well logs data to create a seismic wavelet that will be correlated with the original seismic cube in order to improve the resolution of the coal beds. A preliminary image is shown in Fig 11 where coal beds picks from well logs are transformed to a seismic wavelet and refine the resolution. Plotting the difference in velocities it is easy to see the coal beds (yellow) and other lithology (blue).

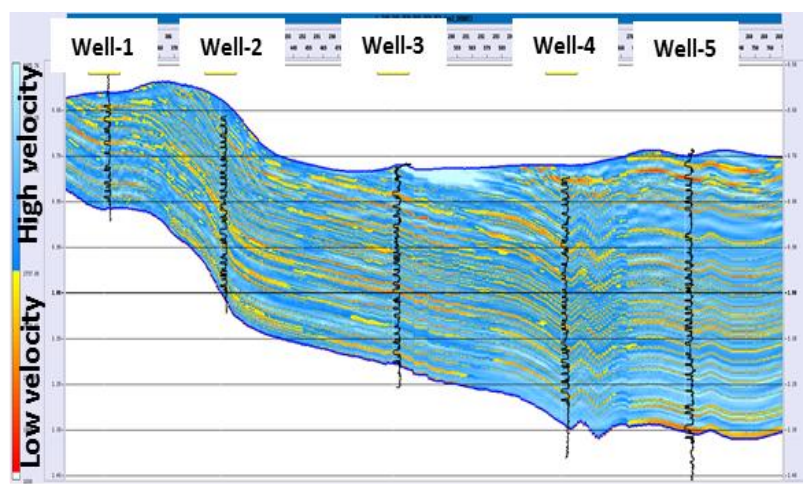

Figure 11 - Preliminary image of Inversion process.

\section{Conclusions}

It is clear that the best geophysical method today to image a very important underground coal deposit like the San Juan del Molino in Guajira- Colombia was the acquired 3D seismic.

The very important drilling exploration campaign that is the actual test of the economic resource present in the area would not be enough to visualize the real geological model.

Within the objectives seeking to future with the additional mentioned processing work, it is expected to achieve a more detailed seismic image that makes possible to refine surfaces (faults and horizons) and to detail some coal beds. In Figure 11 the inversion is aimed to refine the resolution of coal beds (yellow) and is projected to define seams of 3-5 m thickness. The work of interpretation should then be refined and the present model will be filled with the different coal layers identified with the drilling exploration campaign.

The resulting maps of the top and base of the coal deposit compound the first step for the design of the biggest underground coal mine in Colombia. 


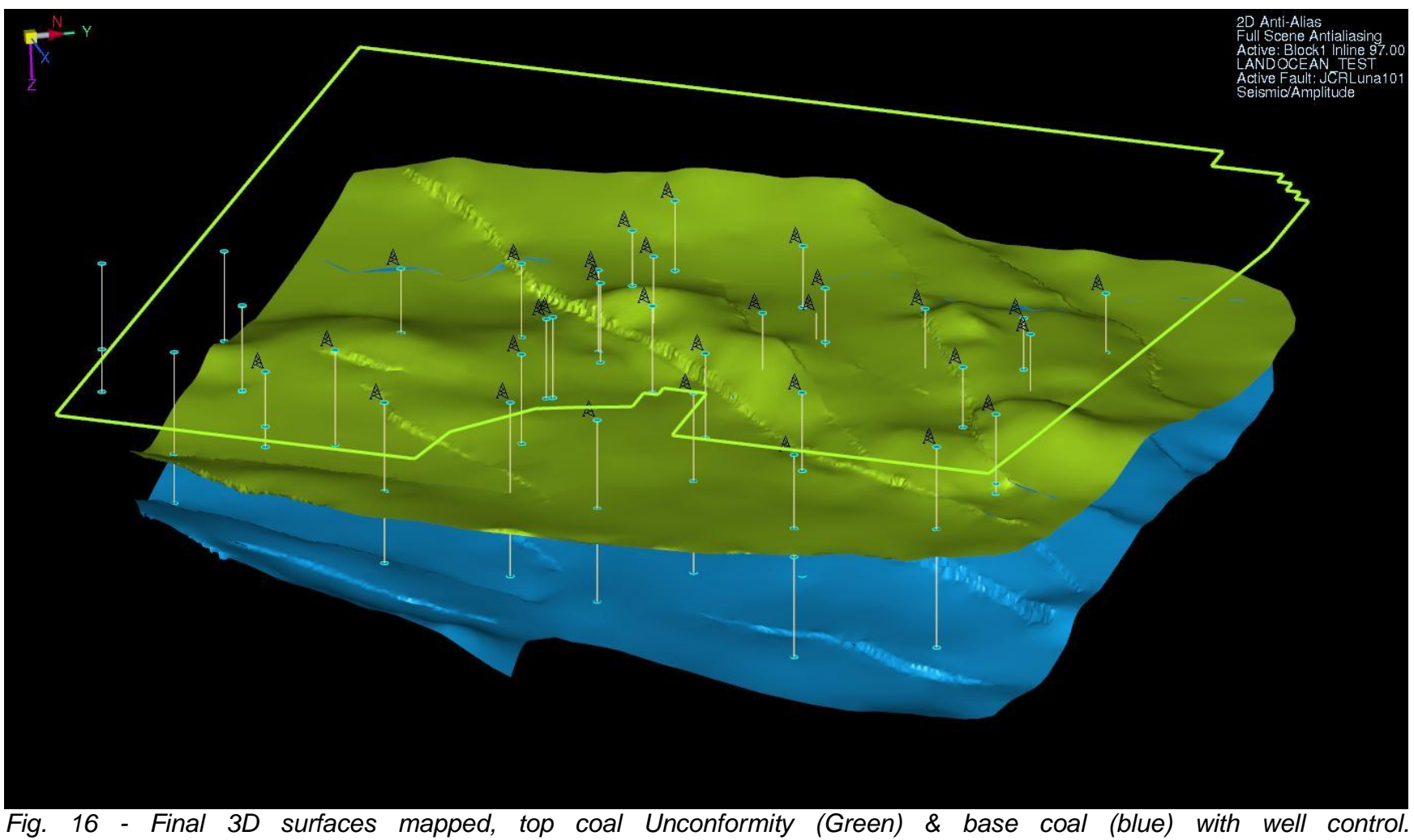

\section{Acknowledgments}

We thank the EBX group and their companies CCX \& OGX for the permission to use the data and our working time for academic purposes.

\section{References}

Barrero, D., Pardo, A., Vargas, C. \& Martinez, J.M., 2007. Colombian sedimentary basins: Nomenclature, Boundaries and petroleum geology a new proposal. Agencia Nacional de Hidrocarburos - ANH 2007.

Bayona, G., Jaramillo, C., Rueda, M., Pardo, A., Christie, A., \& Hernandez, G. (2004). Important paleotectonic and chronostratigraphic considerations of the Late Paleocene in the Northernmost Andes as constrained by Paleocene rocks in The Cerrejón Coal Mine, Guajira, Colombia. Memorias en CD de la Tercera Convención Técnica de la Asociación Colombiana de Geólogos y Geofísicos del Petróleo, Bogotá.
Jaramillo, C., Bayona, G., Pardo, A., Rueda, M., Torres, V., Harrington, G. \& Mora, G., 2007. The palynology of the Cerrejón formation (Upper paleocene) of northern Colombia. Palynology, volume 31.

Bayona, G., Montes, C., Cardona, A., Jaramillo, C., Ojeda, G., Valencia, V. \& Ayala-Calvo, C. (2011). Intraplate subsidence and basin filling adjacent to an oceanic arc-continente collision: a case from the southern Caribbean-South America plate margin. Basin Research (2011) vol. 23: 403-422.

www.cerrejon.com/site/sala-de-prensa/cifrascerrejon.aspx, 2012 